\title{
The Impact of Chatbots on the Relationship between Integrated Marketing Communication and Online Purchasing Behavior in The Frontier Market
}

\author{
Bui Thanh Khoa \\ ORCID iD: 0000-0002-9878-2164, Finance, Economics and Management Research \\ Group, Ho Chi Minh City Open University, 35-37 Ho Hao Hon Street, District 1, Ho \\ Chi Minh City, Vietnam \\ *Corresponding author, e-mail: khoa.bt@ou.edu.vn
}

\begin{abstract}
Artificial Intelligence (AI), applied in many fields, is the core of the fourth technological revolution. In business, AI is used for customer relationship management as applied in the autoresponder systems, i.e., chatbot. Chatbots were an essential tool in the marketing relationship as many companies applied this function to their website; hence, this study analyzed the influence of chatbots on the enterprise's integrated marketing communication (IMC) activities, resulting in impulse purchase behavior and repurchase intention behavior. The mixed research method was used, particularly the in-depth interview and the survey with 886 online consumers, who shop from the online websites with chatbots system in Vietnam as Tiki, Lazada, Sendo, excetera. The research results showed that the perceived usefulness and ease of use of chatbots have positively affected the attitude of online consumers to the IMC activities of businesses. Simultaneously, IMC leads to impulse buying as well as the repurchase intention behavior of customers. The study proposed some managerial implications for an online business to enhance the chatbot functions to consumer behaviors in the website.
\end{abstract}

Keywords: Integrated Marketing Communication, Impulse Purchase Behavior, Repurchase Intention Behavior, Chatbots, Vietnam.

\section{Introduction}

Chatbots are heavily used globally in education (Kane, 2016; Smutny \& Schreiberova, 2020); healthcare service, or medical purposes (Chukhleb, 2020; Viswanath Prakash \& Das, 2020); banking (Li et al., 2020). However, the research into the application of chatbots in integrated marketing communication in the electronic commerce industry, the central customer concept (Schultz, 2016), has not been paid attention to by the scientific community. Although expected as a new communication channel to make a difference between online businesses, chatbots are only used as a temporary tool to replace customer care staff when they can not answer customers directly (Van den Broeck et al., 2019). Another critical point is that IMC analysis research is still concentrated in developed countries or managers' points, although the customer-centric view or the emerging and frontier markets are potential for behavior science or economic growth; therefore, it is crucial to consider that IMC is significant in frontier markets (Schultz et al., 2016; Wagner Mainardes et al., 2019). Another consideration is that the enterprise IMC impact studies focus on two dimensions, i.e., customer-oriented and technology-oriented, which are the generic concepts of a technology (Butkouskaya et al., 2020; Peltier et al., 2003). Based on the Technology Acceptance Model (TAM), the perceived usefulness can be considered customeroriented, and the perceived ease of use is related to the technology-oriented system (Davis, 1989). Finally, the business cares about the customers' behavior, which is influenced by its communications activities. Advertising and public relation aim to

Article History: Received July 01, 2020; Revised May 03, 2021; Accepted August 13, 2021; Published September 09, 2021 
create consumers' awareness and perception, while direct marketing, sale promotion, and personal selling contribute to consumer behavior (Kotler et al., 2019). IMC has a positive effect on customer purchase behavior (Finne \& Grönroos, 2009). Moreover, after-sale services are essential to enhance customer retention (Khoa, 2020a, 2020b). However, purchase intention has been focused more than impulse purchase behavior, repurchase intention behavior (Khoa, Nguyen, \& Nguyen, 2020).

According to a DMA's email report in 2018, the percentage of customers opening marketing emails is $18.1 \%$, and Click-through rates are $1.9 \%$. It shows that the rate of businesses reaching customers via email is meager, not creating the effectiveness of business communication activity. However, with the rise of social media and instant messaging applications, email marketing has reduced the dominance of online media (Khoa, Ha, et al., 2022). 55\% of customers prefer to use messaging apps to communicate with businesses (Vova, 2019). More than 100.000 developers are currently building chatbots for the Facebook Messenger platform. It gives credibility to the theory that the best form of advertising in the future will come from a mixed service of humans and chatbots (Rouhiainen, 2018). 47\% of consumers are open to buying items through a chatbot, and $37 \%$ purchase items from Facebook (Vova, 2019). In essence, chatbots are computer programs that carry conversations through text or audio. There are two basic types of chatbot technology, including the operation of the first type follows a simple, predefined rule, while the second type runs with AI. One of the main benefits of using chatbots is that they can speed up communications by providing a 24/7 feedback system (Dawar \& Bendle, 2018). People then only receive conversation when questions or problems cannot be answered or solved by the chatbot. A key factor paving the way for chatbot use is the increasingly crowded mobile app ecosystem. While the mobile apps market may be saturated, most smartphone owners only use a few mobile apps daily (Khoa, 2020d).

This issue creates a perfect environment for chatbots to catch up. Chatbots are still a relatively new communication tool, which is the conversational interface, making it an attractive option for those looking to try something else (Zarouali et al., 2018). The rapid development of chatbots comes with four main advantages (Winkler \& Soellner, 2018) including, (1) Cost savings because they can replace assistants, i.e., chatbots can help reduce customer care costs by $30 \%$ (Trips, 2017); (2) Increase user satisfaction by responding quickly and respond anytime, anywhere (Dawar \& Bendle, 2018); (3) chatbots can track users from location to transaction history to display what users are looking for; (4) chatbots are also an excellent business analytics tool because user-tochat conversations can be automatically analyzed to understand customer requirements better, and thus improve products and services. The use of chatbots as a communication tool will enhance consumer shopping behavior, including impulse purchase behavior and repurchase behavior. With the development of electronic commerce, information technology in the emerging marketing as Southeast Asian countries, South American countries, this research aims to discover the relationship between the chatbots application attributions (i.e., the perceived usefulness and perceived ease of use) and the customer-IMC based on the TAM; and the relationship between the customer-IMC and purchase behavior (i.e., the impulse purchase behavior and the repeat purchase behavior). The research contributed to the theory about applying chatbots, which is new communication technology in digital marketing theory, and the managerial implication for the online business in the competitive market environment.

Frontier economy or pre-emerging economy is less developed capital markets in 
developing countries. The frontier market is a country, which is more developed than the least developed but still too small, too risky for capital, or too low liquidity to be ranked as an emerging market (Eckstein et al., 1974). Many investors pursue marginal capital markets because they have the potential for high returns. Because many frontier markets do not have a developed stock market, investments are typically private or direct investments in infrastructure and startups (Dana, 1994). While significant gains can be made in investing in the frontier economy, investors must also accept higher risks than investments in the US, Europe, or any other country belonging to the G7 group. Investors' risks in frontier markets are political instability, inferior liquidity, inadequate regulations, substandard financial statements, and significant monetary fluctuations. Also, many markets rely too much on highly volatile commodities (Schneider, 1995). However, technology adoption and innovation occur easily and quickly in industrial economies but are more complicated and challenging in poorer countries. Many of the research in business sociology pointed out that inadequate access to information is the main reason leading to low innovation (Kerr, 2008; Nguyen \& Khoa, 2021). Therefore, technology in enterprises' IMC activities will produce different research results between the developed, emerging, and frontier economies.

Integrated marketing is a tool of business to carry out the communication function of promotion, an essential component in the 4P of Marketing (Kotler et al., 2019). The traditional communication model, which business-centre IMC, emphasizes the critical elements in an effective communication system. Businesses must communicate information to the target audience and specify what response they want from the public. Companies must encode their messages in a way that takes into account the normal process of decoding the message to the public. The sender must select the appropriate media and design feedback channels to know the recipient's response to that message. However, customer-center IMC activities are business communication for customers (Finne \& Grönroos, 2009). After receiving the message, customers will select and combine the messages collected from many communication channels: websites, email marketing, or chatbots. Chatbots will create many impressions for customers about the communication strategy. With AI development, chatbots help users become more accurate and tailored to customers' needs, thereby creating value for users when shopping online (Van den Broeck et al., 2019).

The S-O-R model was proposed by Mehrabian and Russell (1974) and is used in many behavioral science fields. The S-O-R model consists of three components; the Stimulus (S) will affect Organism (O), finally generate Response (R) from customers. Based on the SOR model, this study builds and tests a research model on the relationship between ease of use and usefulness of chatbots, the value of IMC experience, and customer purchase behavior of online customer shopping in an emerging market.

Purchase behavior is the actual action that consumers reveal during exchanging products; including, investigating, purchasing, using, evaluating, and spending on goods and services to satisfy their needs (Kotler et al., 2019). The concept of initial purchase often exists in B2B market studies (Kotler et al., 2019). However, in a fiercely competitive market today, the concept of initial purchase is gradually getting the attention of businesses in not only B2B but B2C. Creating a new customer in a saturated market is something that companies need to consider. Customers often have to intend on products for traditional purchases and then go to the store to shop. Customers will be easily stimulated by the company's IMC activities when they accidentally visit an ecommerce site, leading to impulsive shopping behavior. Therefore, creating a new 
customer list for e-commerce sites is not too difficult. In some studies, impulse purchase behavior has been known to increase consumers' lives simply because they want to experience the feeling of shopping, relieving the mind when done the act of buying something that they like (Wood, 2005). The impulse purchase behavior is associated with the decision to buy quickly, more emotional than rational (Rook, 1987; Rook \& Hoch, 1985), and does not include buying a product to fulfill a predetermined purpose (Beatty \& Ferrell, 1998).

However, the critical issue that determines a business's existence is whether customers continue shopping on e-commerce sites or not? The customer's repurchase behavior expresses the answer to that problem after the first purchase due to improvisation. Repurchase behavior is an expression of customer loyalty (Khoa, 2020a). Customers are willing to invest in loyalty when they provide superior value to competitors' services (Reichheld \& Schefter, 2000). The intention to repurchase refers to the possibility of using a service provider again in the future (Fornell, 1992). Boonlertvanich (2011) defined repurchasing intent as the ability to use a brand again in the future.

\section{Methods}

Perceived usefulness of technology was that consumers find that using technology in purchases saves them time, effort, and they can make purchases, thereby increasing acceptance and intention to use it in the future. Perceived ease of use, which is an essential factor in the TAM, is the level at which a person believes that using a particular system will require no effort (Davis, 1989; Khoa, Nguyen, Tran, et al., 2020). Integrated communication emphasizes the relationship between the provided content and customers' information needs (Bruhn \& Schnebelen, 2017; Khoa, Huynh, et al., 2020). The user-oriented dimension of chatbots will better satisfy the information needs of customers; chatbots will answer the question "what is beneficial for purchasing?" and "how to buy?" (Narver \& Slater, 1990). Thereby, it will build a two-way relationship between customers and businesses. Therefore, chatbots will be able to influence customers' experience of business communication positively. It is impossible to ignore the ease of use in technology adoption (Khoa et al., 2021). In the context of the technological revolution, technology's rapid change creates enormous pressure on users, such as customers (Khoa, 2020c; Schultz, 2016). A typical activity of mobile commerce services is that consumers do not interact directly with service providers. Therefore, ease of learning and using is crucial for chatbots regardless of whether consumers are technically proficient (Dai \& Palvi, 2009). Therefore, the use of easy chatbots will positively affect the perception of the value of communication activities (Ndubisi et al., 2008) and the usefulness of chatbots themselves (Davis, 1989).

Communication activities are an essential activity of all businesses; however, it is a complex activity that requires the active participation of both businesses and customers. When there is a need for information, customers often use many IMC tools as advertising, personal sales, or email marketing from different sources, i.e., companies, competitors, communes (Finne \& Grönroos, 2009). Therefore, if the information from the communication activities is incorrect, it will lead to false perception values and affect IMC activities (Lee \& Park, 2007). Chatbots are used as a direct response and interactive marketing tool to enable businesses and customers to provide two-way information online. Consumers can receive instant advice such as selling and purchasing impulse purchasing (Villarreal, 2010). Currently, businesses 
focus primarily on web-based marketing communications to influence impulse purchasing (Al Khattab et al., 2015). Besides, repurchase behavior is essential in customer behavior research (Khoa, 2020b; Schultz, 2016). Customer repurchase behavior depends on various factors, including evaluating business communication (Lee \& Park, 2007). Communication content inconsistent with consumers' views can negatively affect consumer trust and long-term relationships (Bruhn \& Schnebelen, 2017; Moon et al., 2017). Therefore, IMC activity will affect the impulse purchase behavior and the intention of repeating when buying online. Moreover, impulse buying had an impact on repurchase intention (Lee, 2011). Hence, it can be inferred that consumer experience through impulse in the purchasing process directly affects customer satisfaction leading to post-purchase behavior such as intent to buy back and word of mouth (Hamza, 2013). The study proposed hypotheses:

H1: The perceived usefulness of chatbots positively affects customer-centered IMC in e-commerce

$\mathrm{H} 2$ : The perceived ease of use of chatbots positively affects customer-centered IMC in e-commerce

H3: The perceived ease of use of chatbots positively affects the perceived usefulness in e-commerce

H4: Customer-centered IMC positively affects impulse purchase behavior in ecommerce

H5: Customer-centered IMC positively affects repurchase intention in e-commerce

H6: The impulse purchase behavior positively affects repurchase intention in ecommerce

This study focused on online companies, which lead the online market in Vietnam as Tiki, Lazada, and also Sendo. The quantitative method was applied to explore this study's new ideas related to the research problem (Khoa, Hung, et al., 2022). The results of in-depth interviews showed that the scales of perceived ease of use (PEOU) and perceived useful (PU) was initially adopted from the study of Khoa, Nguyen, Tran, et al. (2020) to fit with the use of chatbots in e-commerce, including four items of PEOU construct and four items of PU construct. Customer-centered IMC (CIMC) consists of 5 items, and repurchase intention behavior (RIB) consists of 3 items, adapted from the research results of Butkouskaya et al. (2020). Impulsive buying behavior (IPB) was measured with three items referenced and corrected from Liu et al. (2013). In total, there are five constructs in this research model, including 19 items designed in the form of a 5-point Likert scale with 1: Strongly disagree, 2: Disagree, 3: Neutral, 4: Agree, 5: Strongly agree.

The participants are consumers living and working in Vietnam, a country with a frontier economy according to the statistics of Morgan Stanley Capital International (2020), and using chatbots during the online purchase process through electronic devices (i.e., smartphones, tablets, and laptops). Analytical data was collected using non-probability sampling by a purposive sampling method, suitable for differences in consumer behavior (Zikmund et al., 2013). The study surveyed 900 consumers after 886 remaining screening questions were appropriate for further analysis. The information about the participants presents in Table 1 . In gender, number of male is 493, accounting for $55.64 \%$. The age of respondent focus from 26 to 35, accounting for $52.37 \%$. Because, peoplr often shopping online in this age group. Furthemore, 321 respodents are office worker, $40.86 \%$ of respondents is housewife. Thus, the collected data ensure the proper implementation of the research model. Survey data is processed by SmartPLS 
software 3.2.7 through the measurement models assessment; i.e., the reliability of the scale, convergent validity, discriminant validity; and the structural model assessment; i.e., collinearity, path coefficient, coefficient of determination, effect size, predictive relevance (Joseph F. Hair et al., 2017).

Table 1. Sample Description

\begin{tabular}{ccc}
\hline & $\mathrm{N}$ & $\%$ \\
\hline Male & 493 & 55.64 \\
Female & 393 & 44.36 \\
$18-25$ & 212 & 23.93 \\
$26-35$ & 464 & 52.37 \\
$36-45$ & 210 & 23.70 \\
Student & 203 & 22.91 \\
Office Worker & 321 & 36.23 \\
Housewife & 362 & 40.86 \\
\hline
\end{tabular}

Note: The study surveyed 900 consumers after 886 remaining screening questions were appropriate for further analysis

\section{Results}

Chatbot has become an essential means for the business to communicate to online customers who shop from the website. The research results showed that the perceived usefulness and ease of use of chatbots have positively affected the attitude of online consumers to the IMC activities of businesses. Simultaneously, IMC leads to impulse buying as well as the repurchase intention behavior of customers

In the first part, the research will assess the reliability of the scale via Cronbach's Alpha (CA); the convergent validity via the Composite Reliability (CR), the Average Variance Extracted (AVE), and outer loading; and the discriminant validity via the Heterotrait-Monotrait Ratio (HTMT). The assessment thresholds are in Table 2.

Table 2. The thresholds for the Reliability and Validity Assessment

\begin{tabular}{ccc}
\hline Assessment & Criterion & Threshold \\
\hline The reliability & Cronbach's alpha (CA) & $\geq 0.7$ \\
& Outer loading & $\geq 0.708$ \\
Convergent validity & Composite Reliability (CR) & $\geq 0.7$ \\
& Average Variance Extracted (AVE) & $\geq 0.5$ \\
Discriminant validity & Heterotrait-Monotrait Ratio (HTMT) & $\leq 0.85$ \\
\hline
\end{tabular}

Note: Adapted from Hair Jr et al. (2016)

The construct reliability and validity assessment are present in Table 3 . The minimum Cronbach's Alpha coefficient is 0.735, which is more than 0.7; therefore, all constructs in the research are reliable. Furthermore, the lowest Composite Reliability of all constructs in this research is 0.85 , more than 0.7. The minimum of Average Variance Extracted is 0.653 , which is higher than 0.5. Moreover, the minimum outer loading index of each construct in the research is more than 0.708 . Hence, all constructs in the research got convergent validity. 
Table 3. The outer loading, CA, CR, AVE of the scales

\begin{tabular}{|c|c|c|c|c|c|c|c|c|}
\hline & CIMC & IPB & PE & PEOU & RIB & CA & CR & AVE \\
\hline CIMC1 & 0.869 & & & & & \multirow{5}{*}{0.867} & \multirow{5}{*}{0.904} & \multirow{5}{*}{0.655} \\
\hline CIMC2 & 0.750 & & & & & & & \\
\hline CIMC3 & 0.827 & & & & & & & \\
\hline CIMC4 & 0.838 & & & & & & & \\
\hline CIMC5 & 0.756 & & & & & & & \\
\hline IPB1 & & 0.815 & & & & \multirow{3}{*}{0.735} & \multirow{3}{*}{0.850} & \multirow{3}{*}{0.653} \\
\hline IPB2 & & 0.790 & & & & & & \\
\hline IPB3 & & 0.819 & & & & & & \\
\hline PU1 & & & 0.840 & & & \multirow{4}{*}{0.870} & \multirow{4}{*}{0.911} & \multirow{4}{*}{0.72} \\
\hline PU2 & & & 0.852 & & & & & \\
\hline PU3 & & & 0.856 & & & & & \\
\hline PU4 & & & 0.847 & & & & & \\
\hline PEOU1 & & & & 0.825 & & \multirow{4}{*}{0.868} & \multirow{4}{*}{0.911} & \multirow{4}{*}{0.718} \\
\hline PEOU2 & & & & 0.788 & & & & \\
\hline PEOU3 & & & & 0.916 & & & & \\
\hline PEOU4 & & & & 0.856 & & & & \\
\hline RIB1 & & & & & 0.866 & \multirow{3}{*}{0.827} & \multirow{3}{*}{0.897} & \multirow{3}{*}{0.743} \\
\hline RIB2 & & & & & 0.862 & & & \\
\hline RIB3 & & & & & 0.858 & & & \\
\hline
\end{tabular}

\section{Note: The Construct Reliability and Validity Assessment}

The discriminant validity between the two constructs ensures the difference, and there is no correlation between measuring factors. This study used HTMT coefficients to confirm the discriminant validity (Joseph F. Hair et al., 2017). According to Table 4, we have the value of the HTMT among the constructs is less than 0.85 , showing the guarantee of discriminant validity.

Table 4. HTMT value

\begin{tabular}{lllll}
\hline & CIMC & IPB & PU & PEOU \\
\hline IPB & 0.661 & & & \\
PU & 0.428 & 0.438 & & \\
PEOU & 0.640 & 0.534 & 0.389 & \\
RIB & 0.467 & 0.480 & 0.357 & 0.352 \\
\hline
\end{tabular}

Note: Author's analysis

In the second part, the Partial Least Squares Structural Equation Modeling (PLSSEM) was verified by five steps process, which has the bootstrap procedure with 5000 random subsamples, including five steps below in Table 5 (Joseph F. Hair et al., 2017) as (1) Collinearity is assessed via the VIF value, which is less than 3; (2) The path coefficient is assessed p-value, which is less than 0.05; (3) Coefficient of Determination $\left(\mathrm{R}^{2}\right.$ value) is $0.75,0.50$, or 0.25 , respectively, described as the substantial, moderate, or weak; (4) Effect Size ( $\mathrm{f}^{2}$ value) is 0.02, 0.15, and 0.35, respectively, has small, medium, and significant effects; finally, Predictive Relevance $\left(\mathrm{Q}^{2}\right.$ value $)$ is more significant than 0 . Table 5 showed the result of VIF, $\mathrm{R}^{2}, \mathrm{f}^{2}$, and $\mathrm{Q}^{2}$. The maximum VIF in table 6 is 1.39 , and all the VIF values are smaller than 3; therefore, the constructs in the research do not 
have collinearity with the others. Moreover, the CIMC, IPB, PU, and RIB have been explained by $34.7 \%, 28.1 \%, 21.5 \%$, and $29.6 \%$ by the change of independent variables. Although the $\mathrm{R}^{2}$ is less than $50 \%$, they can accept that due to the $\mathrm{R}^{2}$ value, it can be allowed with $20 \%$ in behavioral science (Joseph F Hair et al., 2017). The CIMC has a large effect on the IPB ( $\mathrm{f}^{2}$ value is 0.39 ); PEOU has a large effect on the CIMC ( $\mathrm{f}^{2}$ value is 0.369). Furthermore, PEOU has a medium effect size on the PU, of which $\mathrm{f}^{2}$ value is 0.169; CIMC, IPB has a small effect size on the RIB with $\mathrm{f}^{2}$ value, respectively, are 0.067, 0.048; PU has the small effect size on the CIMC with $\mathrm{f}^{2}$ value is 0.059 . Table 5 pointed out all $\mathrm{Q}^{2}$ value are more than $0\left(\mathrm{Q}^{2} \mathrm{CIMC}=0.222, \mathrm{Q}^{2} \mathrm{IPB}=0.180 ; \mathrm{Q}^{2} \mathrm{PU}=0.081\right.$, $\mathrm{Q}^{2} \mathrm{RIB}=0.143$ ).

Table 5. The result of VIF, $\mathrm{R}^{2}, \mathrm{f}^{2}$, and $\mathrm{Q}^{2}$

\begin{tabular}{|c|c|c|c|c|c|c|c|c|c|c|c|}
\hline & \multirow[b]{2}{*}{ CIMC } & \multicolumn{4}{|c|}{ VIF } & \multirow{2}{*}{$\mathrm{R}^{2}$} & \multicolumn{4}{|c|}{$f^{2}$} & \multirow{2}{*}{$\mathrm{Q}^{2}$} \\
\hline & & IPB & PU & PEOU & RIB & & CIMC & IPB & PU & RIB & \\
\hline CIMC & & 1 & & & 1.39 & 0.347 & & 0.39 & & 0.067 & 0.222 \\
\hline IPB & & & & & 1.39 & 0.281 & & & & 0.048 & 0.180 \\
\hline PU & 1.129 & & & & & 0.215 & 0.059 & & & & 0.081 \\
\hline PEOU & 1.129 & & 1 & & & & 0.369 & & 0.169 & & \\
\hline RIB & & & & & & 0.296 & & & & & 0.143 \\
\hline
\end{tabular}

Note: Author's analysis

The path coefficients in Table 6 archived significantly with the $99 \%$ confidence level because the p-value was less than 0.001 . Hence, all the hypotheses were accepted.

Table 6. The Result of PLS-SEM

\begin{tabular}{lcccccc}
\hline & Beta & Std. Deviation & t statistics & p-values & H & Result \\
\hline PU -> CIMC & 0.208 & 0.041 & 5.100 & 0.000 & H1 & Accepted \\
PEOU -> CIMC & 0.485 & 0.043 & 11.327 & 0.000 & H2 & Accepted \\
PEOU -> PU & 0.338 & 0.047 & 7.267 & 0.000 & H3 & Accepted \\
CIMC -> IPB & 0.530 & 0.050 & 10.624 & 0.000 & H4 & Accepted \\
CIMC -> RIB & 0.273 & 0.045 & 6.011 & 0.000 & H5 & Accepted \\
IPB -> RIB & 0.232 & 0.043 & 5.426 & 0.000 & H6 & Accepted \\
\hline
\end{tabular}

Note: Author's analysis

\section{Discussion}

The study was conducted in a frontier economy like Vietnam, different from economic and social conditions than developed or emerging economies. Chatbots is a new technology that helps businesses integrate marketing communications activities when customers use mobile devices to access business websites. The research has applied previous studies to build and reaffirm the relationships between structures such as perceived usefulness, perceived ease of use, customer-centered IMC, impulse purchase behavior, and repurchase intention.

First of all, the first three hypotheses are accepted with a $99 \%$ confidence level. The perceived usefulness of chatbots positively affects customer-centered IMC in ecommerce $($ Beta $=0.208$, p-value $=0.000)$; the perceived ease of use of chatbots positively affects customer-centered IMC in e-commerce $($ Beta $=0.485, \mathrm{p}$-value $=$ 0.000 ); and the perceived ease of use of chatbots positively affects the perceived usefulness in e-commerce (Beta $=0.338, \mathrm{p}$-value $=0.000$ ). In particular, customers in the frontier economy are more interested in ease of use than useful. What stands out in this research is that the customer-centric IMC concept is considered in terms of customer attitudes. Therefore, the research results are in line with Davis's technology acceptance 
theory (Davis, 1989) and the empirical studies of other researchers related to technology (Lee, 2009; Luan \& Teo, 2009) and chatbots (Rietz et al., 2019; Winkler \& Söllner, 2018). If compared with the research of Butkouskaya et al. (2020), this result also creates a certain consensus if considering perceived usefulness as customer-oriented decision-making and perceived ease of use is technology-oriented decision-making. Therefore, the application of chatbots needs to be invested by businesses in both technical aspects and content. In the frontier market, mainly in developing countries, the technical level of customers is not high; therefore, the use of an automated communication system can cause difficulties for customers. Therefore, businesses need to use reputable chatbots systems, which should avoid technical errors that make customers confused in use. Besides, there should be a user guide located on the website to teach customers how to comunicate through chatbots. Usefulness also affect the perception of business communication. Hence, an online business needs to research questions frequently to complement the database of chatbots. In addition, it is possible to integrate the feature of introducing promotion programs during the display of chatbots to create more information for customer.

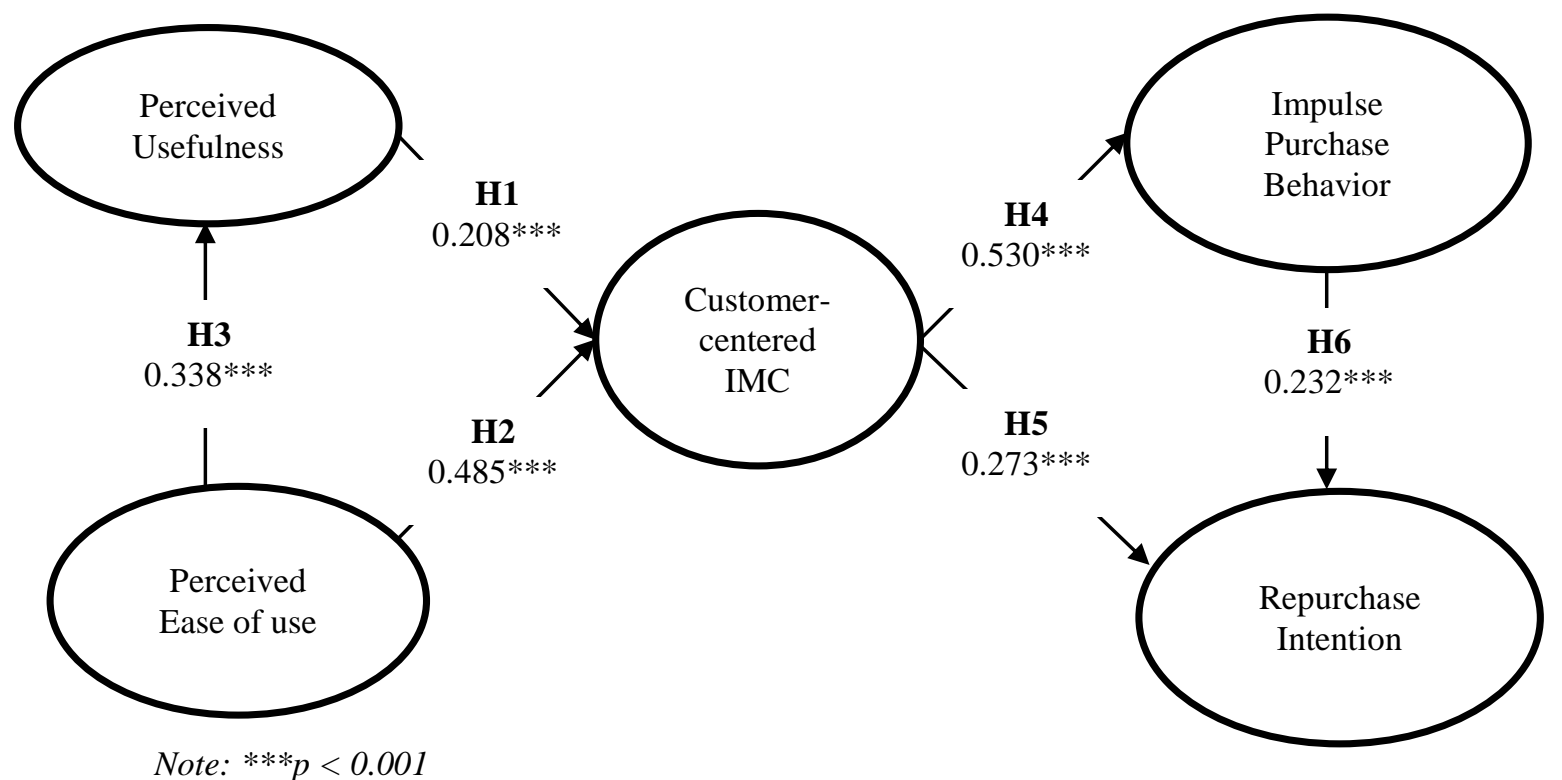

Figure 1. Hypotheses testing (source: Author's analysis)

Secondly, this study also pointed the customer-centered IMC activities, which related the chatbots, will positively impact on the impulse purchase behavior (Beta $=$ $0.530, \mathrm{p}$-value $=0.000)$; repurchase intention $($ Beta $=0.273$, $\mathrm{p}$-value $=0.000)$; and the impulse purchase behavior has the positive effect on repurchase intention (Beta $=0.232$, p-value $=0.000)$. In particular, improvising purchases is strongly influenced by IMC activities through chatbots of the business on the website. This study shows that AI technology, i.e., chatbots are a factor that influences consumer emotions and leads to impulse purchasing behavior, and may also lead to customers' repurchase intention behavior on websites (Lim \& Kim, 2020; Liu et al., 2013). Besides, the study reinforces a positive view of buy-back after the first impulse purchase (Lee, 2011). Thereby, the business should promote the effective use of chatbots in IMC activities on the website through several solutions such as enhancing the building of information in chatbots that are up-to-date and suitable to customers' needs. Because customers access business information through multiple communication channels, another important thing is that there is information consistency between chatbots and corporate policies. 


\section{Conclusion}

This study has contributed to both academic research and managerial practice. Theoretically, the study has built a research model based on the technology adoption model in the context of related integrated marketing communication leading to impulse buying and repurchase intention of online consumers. The study also contributes to and reaffirms behavioral theories in the online environment at the frontier economy. Besides, the research results have brought some positive results that can apply in practice. First, research has shown chatbots to be a communication tool that can lead to shoppers' behaviors, including impulse purchase and repurchase intention. Thereby, businesses need to pay attention to this tool when building websites or applications for online selling. Also, the study pointed that for the frontier markets, the ease of use of chatbots is essential for customers to create awareness about the enterprise's integrated communication marketing activities. Although many efforts have been made in research, its limitations are inevitable. Firstly, the research was conducted in only one frontier market, Vietnam, so the research results were not highly representative. Also, customer post-purchase behavior in this study is focused solely on repurchase intention behavior. Finally, this study relies only on the TAM to focus on two main aspects of chatbots, including perceived ease of use and perceived usefulness, thus limiting other aspects of chatbots affecting perceptions of IMC operations of the business. The above limitations may create opportunities for further research in the same area of integrated communication or e-commerce. Extensive research is essential to verify and collate research results; therefore, future research is possible in other frontier economies in Europe, Africa, or the Middle East of Morgan Stanley Capital International (2020). Besides, the expansion of post-purchase behaviors such as word of mouth, satisfaction, commitment is also needed to be considered to understand better customer behavior under the influence of IMC activities related to chatbots. The motivation for chatbot using such as productivity, entertainment, social, and curiosity (Brandtzaeg \& Følstad, 2017) may be more specific prefixes for analysis in subsequent studies.

\section{Conflict of Interest}

I certify no conflict of interest with any financial, personal, or other relationships with other people or organizations related to the material discussed in the manuscript.

\section{Acknowledgements}

The authors would like to thank all respondents (886 online consumers) in this study, for their responses during the time of the survey.

\section{References}

Al Khattab, S. A., As'ad, H., \& Zaidan, G. M. (2015). E-Integrated Marketing Communication and its impact on customers' attitudes. American Journal of Industrial and Business Management, 5(08), 538-547.

Beatty, S. E., \& Ferrell, M. E. (1998). Impulse buying: Modeling its precursors. Journal of Retailing, 74(2), 169-191.

Boonlertvanich, K. (2011). Effect of customer perceived value on satisfaction and customer loyalty in banking service: The moderating effect of main bank status. International Journal of Business Research, 11(6), 40-54. 
Brandtzaeg, P. B., \& Følstad, A. (2017). Why people use chatbots. International Conference on Internet Science, Thessaloniki, Greece.

Bruhn, M., \& Schnebelen, S. (2017). Integrated marketing communication-from an instrumental to a customer-centric perspective. European Journal of Marketing, 51(3), 464-489. https://doi.org/10.1108/EJM-08-2015-0591

Butkouskaya, V., Llonch-Andreu, J., \& Alarcón-del-Amo, M.-d.-C. (2020). InterCountry Customer-Perspective Analysis of Strategic Antecedents and Consequences for Post-Purchase Behaviour in Integrated Marketing Communications (IMC). Journal of International Consumer Marketing, 1-16. https://doi.org/10.1080/08961530.2020.1731901

Chukhleb, M. (2020). The application chatbots in medical purposes. Язылк в сфере профессиональной коммуникации.-Екатеринбург, 2020, 743-747.

Dai, H., \& Palvi, P. C. (2009). Mobile commerce adoption in China and the United States: a cross-cultural study. ACM SIGMIS Database: the DATABASE for Advances in Information Systems, 40(4), 43-61.

Dana, L. P. (1994). A Marxist mini-dragon? Entrepreneurship in today's Vietnam. Journal of Small Business Management, 32(2), 95-102.

Davis, F. D. (1989). Perceived Usefulness, Perceived Ease of Use, and User Acceptance of Information Technology. MIS Quarterly, 13(3), 319-340. https://doi.org/10.2307/249008

Dawar, N., \& Bendle, N. (2018). Marketing in the age of Alexa. Harvard Business Review, 96(3), 80-86.

Eckstein, A., Chao, K., \& Chang, J. (1974). The economic development of Manchuria: the rise of a frontier economy. The Journal of Economic History, 239-264.

Finne, A., \& Grönroos, C. (2009). Rethinking marketing communication: From integrated marketing communication to relationship communication. Journal of Marketing Communications, 15(2-3), 179-195.

Fornell, C. (1992). A national customer satisfaction barometer: The Swedish experience. Journal of Marketing, 56(1), 6-21.

Hair, J. F., Hauff, S., Hult, G. T. M., Richter, N. F., Ringle, C. M., \& Sarstedt, M. (2017). Partial Least Squares Strukturgleichungsmodellierung. Sage publications. https://doi.org/10.15358/9783800653614

Hair, J. F., Sarstedt, M., Ringle, C. M., \& Gudergan, S. P. (2017). Advanced issues in partial least squares structural equation modeling. Sage Publications. https://doi.org/10.1007/978-3-319-05542-8_15-1

Hair Jr, J. F., Hult, G. T. M., Ringle, C., \& Sarstedt, M. (2016). A primer on partial least squares structural equation modeling (PLS-SEM). Sage publications.

Hamza, V. (2013). A study on the mediation role of customer satisfaction on customer impulse and involvement to word of mouth and repurchase intention. International Journal of Business Insights \& Transformation, 7(1), 62-67.

Kane, D. A. (2016). The role of chatbots in teaching and learning. In R. Scott \& N. G. Margaret (Eds.), E-Learning and the Academic Library: Essays on Innovative Initiatives. McFarland \& Company.

Kerr, W. R. (2008). Ethnic scientific communities and international technology diffusion. The Review of Economics and Statistics, 90(3), 518-537.

Khoa, B. T. (2020a). The Antecedents of Relationship Marketing and Customer Loyalty: A Case of the Designed Fashion Product. Journal of Asian Finance, 
$\begin{array}{llll}\text { Economics } & \text { and } & \text { Business, } & 7(2),\end{array}$ https://doi.org/10.13106/jafeb.2020.vol7.no2.195

Khoa, B. T. (2020b). Electronic Loyalty in the Relationship between Consumer Habits, Groupon Website Reputation, and Online Trust: A Case of the Groupon Transaction. Journal of Theoretical and Applied Information Technology, 98(24), 3947-3960.

Khoa, B. T. (2020c). The Perceived Enjoyment of the Online Courses in Digital Transformation Age: The Uses - Gratification Theory Approach 2020 Sixth International Conference on e-Learning (econf), Sakheer, Bahrain. https://ieeexplore.ieee.org/document/9385490/. https://doi.org/10.1109/econf51404.2020.9385490

Khoa, B. T. (2020d). The role of Mobile Skillfulness and User Innovation toward Electronic Wallet Acceptance in the Digital Transformation Era. 2020 International Conference on Information Technology Systems and Innovation (ICITSI), Bandung - Padang, Indonesia. https://doi.org/10.1109/ICITSI50517.2020.9264967

Khoa, B. T., Ha, N. M., \& Ngoc, B. H. (2022). The Accommodation Services Booking Intention Through the Mobile Applications of Generation Y: An Empirical Evidence Based on TAM2 Model. In N. Ngoc Thach, D. T. Ha, N. D. Trung, \& V. Kreinovich (Eds.), Prediction and Causality in Econometrics and Related Topics (pp. 559-574). Springer International Publishing. https://doi.org/10.1007/978-3-030-77094-5_43

Khoa, B. T., Hung, B. P., \& Mohsen, H. (2022). Qualitative Research in Social Sciences: Data Collection, Data Analysis, and Report Writing. International Journal of Public Sector Performance Management, 9(4). https://doi.org/10.1504/ijpspm.2022.10038439

Khoa, B. T., Huynh, L. T., \& Nguyen, M. H. (2020). The Relationship between Perceived Value and Peer Engagement in Sharing Economy: A Case Study of Ridesharing Services. Journal of System and Management Sciences, 10(4), 149172. https://doi.org/10.33168/JSMS.2020.0210

Khoa, B. T., Ly, N. M., Uyen, V. T. T., Oanh, N. T. T., \& Long, B. T. (2021). The impact of Social Media Marketing on the Travel Intention of Z Travelers. 2021 IEEE International IOT, Electronics and Mechatronics Conference (IEMTRONICS), Toronto, ON, Canada. https://doi.org/10.1109/IEMTRONICS52119.2021.9422610

Khoa, B. T., Nguyen, H. M., Tran, N. V. H., \& Nguyen, B. H. (2020). Lecturers' adoption to use the online Learning Management System (LMS): Empirical evidence from TAM2 model for Vietnam. Journal of Science Hcmcou Economics \& Business Administration, 10(1), 3-17. https://doi.org/10.46223/HCMCOUJS.econ.en.10.1.216.2020

Khoa, B. T., Nguyen, T. D., \& Nguyen, V. T.-T. (2020). The intention to purchase designed fashion product of Vietnamese Designer: The mediator of customer relationship. Journal of Business and Retail Management Research, 14(2), 22-32. https://doi.org/10.24052/JBRMR/V14IS02/ART-03

Kotler, P., Keller, K. L., Goodman, M., Brady, M., \& Hansen, T. (2019). Marketing management (4th ed.). Pearson Education. 
Lee, D. H., \& Park, C. W. (2007). Conceptualization and measurement of multidimensionality of integrated marketing communications. Journal of Advertising Research, 47(3), 222-236.

Lee, E.-J. (2011). The effects of internet fashion consumer's impulse buying tendency on positive and negative purchasing behaviors. Fashion \& Textile Research Journal, 13(4), 511-522.

Lee, M.-C. (2009). Factors influencing the adoption of internet banking: An integration of TAM and TPB with perceived risk and perceived benefit. Electronic Commerce Research and Applications, 8(3), 130-141.

Li, C.-H., Yeh, S.-F., Chang, T.-J., Tsai, M.-H., Chen, K., \& Chang, Y.-J. (2020). A Conversation Analysis of Non-Progress and Coping Strategies with a Banking Task-Oriented Chatbot. Proceedings of the 2020 CHI Conference on Human Factors in Computing Systems,

Lim, S. H., \& Kim, D. J. (2020). Does Emotional Intelligence of Online Shoppers Affect Their Shopping Behavior? From a Cognitive-Affective-Conative Framework Perspective. International Journal of Human-Computer Interaction, 1-10.

Liu, Y., Li, H., \& Hu, F. (2013). Website attributes in urging online impulse purchase: An empirical investigation on consumer perceptions. Decision support systems, 55(3), 829-837.

Luan, W. S., \& Teo, T. (2009). Investigating the technology acceptance among student teachers in Malaysia: An application of the technology acceptance model (TAM). The Asia-Pacific Education Researcher, 18(2), 261-272.

Mehrabian, A., \& Russell, J. A. (1974). An approach to environmental psychology. M.I.T. Press.

Moon, S.-J., Costello, J. P., \& Koo, D.-M. (2017). The impact of consumer confusion from eco-labels on negative WOM, distrust, and dissatisfaction. International Journal of Advertising, 36(2), 246-271.

Morgan Stanley Capital International. (2020). MSCI announces the results of the 2020 annual market classification review. Retrieved May 21st from https://www.msci.com/market-classification

Narver, J. C., \& Slater, S. F. (1990). The effect of a market orientation on business profitability. Journal of Marketing, 54(4), 20-35.

Ndubisi, N. O., Malhotra, N. K., \& Wah, C. K. (2008). Relationship marketing, customer satisfaction and loyalty: a theoretical and empirical analysis from an Asian perspective. Journal of International Consumer Marketing, 21(1), 5-16.

Nguyen, M. H., \& Khoa, B. T. (2021). The Google Advertising Service Adoption Behavior of Enterprise in the Digital Transformation Age. Webology, 18(Special Issue on Information Retrieval and Web Search), 153-170. https://doi.org/10.14704/web/v18si02/web18064

Peltier, J. W., Schibrowsky, J. A., \& Schultz, D. E. (2003). Interactive integrated marketing communication: combining the power of IMC, the new media and database marketing. International Journal of Advertising, 22(1), 93-115.

Reichheld, F. F., \& Schefter, P. (2000). E-loyalty: your secret weapon on the web. Harvard Business Review, 78(4), 105-113.

Rietz, T., Benke, I., \& Maedche, A. (2019). The impact of anthropomorphic and functional chatbot design features in enterprise collaboration systems on user acceptance. 
Rook, D. W. (1987). The buying impulse. Journal of Consumer Research, 14(2), 189199.

Rook, D. W., \& Hoch, S. J. (1985). Consuming impulses. ACR North American Advances.

Rouhiainen, L. (2018). Artificial Intelligence: 101 things you must know today about our future. Amazon Asia-Pacific Holdings.

Schneider, R. R. (1995). Government and the Economy on the Amazon Frontier. The World Bank.

Schultz, D. (2016). The future of advertising or whatever we're going to call it. Journal of advertising, 45(3), 276-285.

Schultz, D., Chu, G., \& Zhao, B. (2016). IMC in an emerging economy: the Chinese perspective. International Journal of Advertising, 35(2), 200-215.

Smutny, P., \& Schreiberova, P. (2020). Chatbots for learning: A review of educational chatbots for the Facebook Messenger. Computers \& Education, 151. https://doi.org/10.1016/j.compedu.2020.103862

Trips, R. (2017). How chatbots can help reduce customer service costs by $30 \%$. Retrieved May 04th from https://www.ibm.com/blogs/watson/2017/10/howchatbots-reduce-customer-service-costs-by-30-percent

Van den Broeck, E., Zarouali, B., \& Poels, K. (2019). Chatbot advertising effectiveness: When does the message get through? Computers in Human Behavior, 98, 150157.

Villarreal, R. (2010). Integrated Marketing Communication Strategy. Wiley International Encyclopedia of Marketing.

Viswanath Prakash, A., \& Das, S. (2020). Would you Trust a Bot for Healthcare Advice? An Empirical Investigation. PACIS 2020 Proceedings,

Vova, C. (2019). Chatbots: A new way to communicate with your customers. Retrieved May 12th from https://chatbotslife.com/chatbots-a-new-way-to-communicatewith-your-customers-eled3596c04f

Wagner Mainardes, E., de Almeida, C. M., \& de-Oliveira, M. (2019). e-Commerce: an analysis of the factors that antecede purchase intentions in an emerging market. Journal of International Consumer Marketing, 31(5), 447-468.

Winkler, R., \& Soellner, M. (2018). Unleashing the Potential of Chatbots in Education: A State-Of-The-Art Analysis. Academy of Management Annual Meeting (AOM), Chicago, USA.

Winkler, R., \& Söllner, M. (2018). Unleashing the potential of chatbots in education: A state-of-the-art analysis Academy of Management Annual Meeting (AOM), Chicago, USA.

Wood, M. (2005). Discretionary unplanned buying in consumer society. Journal of Consumer Behaviour: An International Research Review, 4(4), 268-281.

Zarouali, B., Van den Broeck, E., Walrave, M., \& Poels, K. (2018). Predicting consumer responses to a chatbot on Facebook. Cyberpsychology, Behavior, and Social Networking, 21(8), 491-497.

Zikmund, W. G., Carr, J. C., \& Griffin, M. (2013). Business Research Methods. SouthWestern Cengage Learning. 